\title{
Amylin Amyloid Inhibition by Flavonoid Baicalein: Key Roles of its Vicinal Dihydroxyl Groups of the Catechol Moiety
}

\author{
Paul Velander ${ }^{1, \wedge}$, Ling Wu ${ }^{1, \wedge}$, W. Keith Ray ${ }^{1}$, Richard F. Helm ${ }^{1}$, and Bin $\mathrm{Xu}^{1,2,3}$ \\ ${ }^{1}$ Department of Biochemistry, ${ }^{2}$ Center for Drug Discovery, and ${ }^{3}$ Translational Obesity \\ Research Center, Virginia Polytechnic Institute \& State University, Blacksburg, Virginia \\ 24061 \\ ${ }^{\wedge}$ Equally contributed.
}

\section{Supporting Information}

\section{Material and Methods}

Peptides and Other Reagents. Synthetic human amylin was purchased from AnaSpec (Fremont, CA), GenScript Inc. (Piscataway, NJ), or EMD Millipore (Billerica, MA). Amylin stocks were quantified by Pierce BCA protein assay kit (Thermo Fisher Scientific (Waltham, MA). Dimethylsulfoxide (DMSO) was purchased from Fisher Scientific (Pittsburg, PA). Hexafluroisopropanol (HFIP) and thioflavin T (ThT) were purchased from Sigma Aldrich (St. Louis, MO). Baicalein and its analogs were purchased from Indofine Chemical Company (Hillsborough, NJ). Additional natural compounds were purchased from Sigma Aldrich and Cayman Chemical Company (Ann Arbor, MI). Dulbecco's phosphate buffer saline (DBPS) was purchased from Lonza, (Walkersville, MD). 200 mesh Formvar-carbon coated copper grids were purchased from Electron Microscopy Sciences (Hatfield, PA). All solvents used for liquid chromatography-mass spectrometry were LC-MS grade.

Peptide and Natural Compound Preparation. $0.5 \mathrm{mg}$ lyophilized human amylin powder was initially dissolved in $100 \%$ HFIP at a final concentration of 1-2 mM. After 2 hours of incubation at room temperature, the solution was lyophilized and re-dissolved in $100 \%$ DMSO to a final concentration of 1-2 mM. The additional lyophilizing step is employed to eliminate traces of organic solvents present in the synthetic peptide. The latter may affect amylin aggregation. Aliquots were either lyophilized again prior to use for cell-based assays or dissolved directly into DPBS, $10 \mathrm{mM}$ phosphate buffer $\mathrm{pH} 7.4$ or $20 \mathrm{mM}$ Tris- $\mathrm{HCl} \mathrm{pH} 7.4$ for all in vitro assays. All remaining 1-2 mM stocks in $100 \%$ DMSO were stored at $-80{ }^{\circ} \mathrm{C}$ until later use. Natural compounds and ThT (Sigma Aldrich) were dissolved in DMSO (10 $\mathrm{mM})$ and distilled water $(1 \mathrm{mM})$, respectively. These stocks were stored at $-20{ }^{\circ} \mathrm{C}$ until later use. Residual DMSO present in the final concentrations used for all in vitro assays ranged from $0-5.4 \%$. We determined that these DMSO concentrations had negligible effects on amylin amyloid formation as reflected by ThT fluorescence, TEM, or PICUP assays. All reported amylin concentrations were initially quantified based on vendor's estimations. We further retrospectively normalized the quantification by Pierce BCA assay to correct potential peptide quantity overestimation by one vendor (up to 3 to 10 fold). In the initial screening experiments, estimated amylin:compound molar ratio ranges from 1:3 to 1:10. 
Thioflavin T Fluorescence Assay. Fluorescence experiments were performed using a SpectraMax M5 plate reader. All kinetic reads were taken at $25{ }^{\circ} \mathrm{C}$ in low- or medium-binding all black clear bottom Greiner 96 (or 384-well) plates covered with optically clear films and shaked for 10 seconds prior to each reading. ThT fluorescence was measured with excitation wavelength at $444 \mathrm{~nm}$ and emission wavelength at $491 \mathrm{~nm}$. Each kinetic assay consisted of final concentrations of 5-30 $\mu \mathrm{M}$ amylin and optimal concentrations of ThT (typical molar ratio of amylin:ThT is $3: 1$ ). The apparent inhibition constant $\left(\mathrm{IC}_{50}\right)$ values for dose response curves were estimated by multi-parameter logistic nonlinear regression analysis. All experiments were repeated at least two times.

Transmission Electron Microscopy (TEM). 15-30 $\mu \mathrm{M}$ amylin (20 mM Tris-HCl, $2 \%$ DMSO, $\mathrm{pH}$ 7.4) in the presence of a natural compound or vehicle control were incubated for $\geq 48$ hours at $37{ }^{\circ} \mathrm{C}$ with agitation (optimum signal at $60-72$ hours). Prior to imaging analyses, 3 $\mu \mathrm{L}$ of sample were blotted on a 200-mesh formvar-carbon coated grid for 5 minutes, and stained with uranyl acetate (1\%). Both the sample and the stain solutions were wicked dry (sample dried before addition of stain) by filter paper. Prior to taking representative images (obtained by a JEOL 1400 operated at $120 \mathrm{kV}$, a qualitative assessment of the amount of fibrils or oligomers observed were made by scanning each grid quadrant for deposited material. The range of final DMSO concentration (0-5.4\%) that we used had negligible effects on fiber formation.

Photo Induced Crosslinking of Unmodified Proteins (PICUP). Amylin aliquots from a master mix in $10 \mathrm{mM}$ phosphate buffer, $\mathrm{pH} 7.4$ were added separately to $0.6 \mathrm{ml}$ eppendorf tubes containing small molecule inhibitors or DMSO vehicle loaded controls. Crosslinking for each tube was subsequently initiated by adding ris(bipyridyl)Ru(II) complex (RuBpy) and ammonium persulfate (APS) (Amylin:RuBpy:APS ratios were fixed at 1:2:20, respectively), followed by exposure to visible light, emitted from a 150 Watt incandescent light bulb, from a distance of $5 \mathrm{~cm}$ and for a duration of 5 seconds. The reaction was quenched by addition of SDS sample buffer. PICUP was visualized by SDS-PAGE (16\% acrylamide gels containing 6 $\mathrm{M}$ urea), followed by silver staining. Final concentrations for all PICUP reactions included 30 $\mu \mathrm{M}$ amylin, with addition of $150 \mu \mathrm{M}$ of inhibitors. All samples, treated and untreated with specified compounds, contained equal percentage of DMSO for normalization. DMSO content in the reaction, ranging between $0-5.4 \%$, had negligible effects on the results.

Cell Culture and Cell Viability Assays. Cell culture: rat pancreatic INS-1 cells and mouse neuroblastoma Neuro-2A cells are cultured per vendor's instructions. An MTT-based cell viability assay was used. The INS-1 cells or Neuro-2A cells were seeded in 96-well plate at a density of $4 \times 10^{4}$ cells/well. After 24 hours incubation, cells are treated with either human amylin, with or without specified natural compounds. Following another 24 hours incubation, $0.9 \mathrm{mM}$ MTT is added to each well. The reduced insoluble MTT formazan product is then dissolved in SDS- $\mathrm{HCl}$ lysis buffer ( $5 \mathrm{mM} \mathrm{HCl}, 5 \% \mathrm{SDS})$ at $37{ }^{\circ} \mathrm{C}$. Cell viability is determined by measurement of absorbance change at $570 \mathrm{~nm}$ using a spectrometric plate reader. Peptides dissolving buffer treated cells were used as positive control and taken as $100 \%$, and $0.5 \%$ Triton X-100 treated cells at the start of the incubation period with test peptides are used as negative control and taken as $0 \%$. 
MALDI-TOF/TOF Mass Spectrometry. Analyses were performed on an ABSciex 4800 MALDI-TOF/TOF operating in linear positive ion mode using $\alpha$-cyano-4-hydroxycinnamic acid $(4 \mathrm{mg} / \mathrm{ml}$ in 50:50 water:acetonitrile supplemented with $0.1 \%(\mathrm{v} / \mathrm{v})$ trifluoroacetic acid and $10 \mathrm{mM}$ ammonium chloride) as the matrix.

Liquid Chromatography-Mass Spectrometry. Amylin $(15 \mu \mathrm{M})$ in 1X Dulbecco's phosphate buffer containing 2.25\% DMSO (v/v) was incubated for 4 days in the presence and absence of baicalein at a molar ratio of 1:10 (amylin:compound). Peptide solutions were separated using an Acquity UPLC I-class system (Waters, Milford, MA). Mobile phases were 0.1\% $(\mathrm{v} / \mathrm{v})$ formic acid in water (solvent $\mathrm{A})$ and $0.1 \%(\mathrm{v} / \mathrm{v})$ formic acid in acetonitrile (solvent $\mathrm{B}$ ). The separation was performed using a CSH130 $\mathrm{C}_{18} 1.7 \mu \mathrm{m}, 1.0 \times 150 \mathrm{~mm}$ column (Waters, Milford, MA) at $50 \mu \mathrm{L} / \mathrm{min}$ using and a 13 minute gradient from $3-90 \%$ solvent B with the column temperature maintained at $45^{\circ} \mathrm{C}$. Analysis utilized a Synapt G2-S mass spectrometer (Waters, Milford, MA) operated in continuum positive ion "resolution" MS mode using an $\mathrm{HDMS}^{\mathrm{E}}$ acquisition method (high-definition mass spectrometry with alternating scans utilizing low and elevated collision energies with ion mobility separation (IMS) of peptides prior to fragmentation). Both low energy (4 $\mathrm{V}$ and $2 \mathrm{~V}$ in the trap and transfer region, respectively) and elevated energy ( $4 \mathrm{~V}$ in the trap and ramped from 20 to 50 $\mathrm{V}$ in the transfer region) scans were 1.2 seconds each covering the $\mathrm{m} / \mathrm{z}$ range of 50 to 1800 . For ion mobility separation, the IMS and transfer wave velocities were 600 and $1200 \mathrm{~m} / \mathrm{sec}$, respectively. Wave height within the ion mobility cell was ramped from 10 to $40 \mathrm{~V}$. For lock-mass correction, a 1.2 second low energy scan was acquired every 30 seconds of a 100 fmol/ $\mu \mathrm{L}$ [Glu1]-fibrinopeptide B (Waters, Milford, MA) solution (50:50 acetonitrile:water supplemented with $0.1 \%(\mathrm{v} / \mathrm{v})$ formic acid) infused at $10 \mu \mathrm{L} / \mathrm{min}$ introduced into the mass spectrometer via a different source also utilizing a capillary voltage of $3 \mathrm{kV}$.

Statistical Analyses. All data are presented as the mean \pm S.E.M. and the differences were analyzed with an one-way ANOVA analyses for amylin kinetics as implemented within GraphPad Prism software (version 6.0) or with unpaired Student's $t$ test in analyzing the significance in cell viability changes. $p$ values $<0.05$ were considered statistically significant. 


\section{Supplemental Figures}

Figure S1. Chemical structures of the targeted set of natural compounds that have been tested in this work (corresponding to compounds listed in Figure 1A). Vicinal dihydroxyl groups of the catechol moieties are highlighted in red.<smiles>O=c1cc(-c2ccccc2)oc2cc(O)c(O)c(O)c12</smiles>

Baicalein
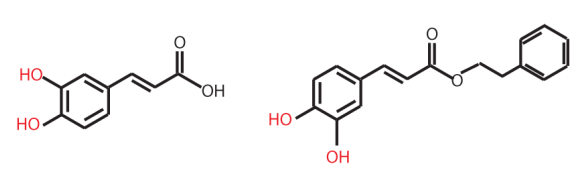<smiles>Oc1cc(O)c2c(c1)OC(c1ccc(O)c(O)c1)C(O)C2</smiles>

Catechin<smiles>O=C(O)/C=C/c1cccc(O)c1</smiles>

m-Coumaric acid<smiles>O=C(O)/C=C/c1ccc(O)cc1</smiles>

p-Coumaric acid<smiles>COc1cc(/C=C/C(=O)CC(=O)/C=C/c2ccc(O)c(OC)c2)ccc1O</smiles>

Curcumin<smiles>Oc1ccc(C2CCCCC2)cc1O</smiles>

Epicatechin<smiles>CC(C)(C)O</smiles>

Epigallocatechin gallate (EGCG)<smiles>Oc1ccc(C2C=CC(O)c3cc(O)cc(O)c32)cc1</smiles>

Genistein<smiles>CCCCC[C@H](O)CC(=O)CCc1ccc(O)c(OC)c1</smiles>

6-Gingerol<smiles>C/C=C1\OC2OC(CO)C(O)[C@H](O)[C@H]2OC1C=C(C(=O)O)C(=O)OCc1ccc(O)cc1</smiles>

Ligstroside<smiles>Oc1ccc(CCOC2OC(O)C(O)C(O)C2O)cc1</smiles>

Salidroside

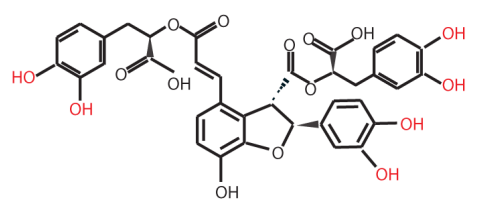

Salvianolic acid B

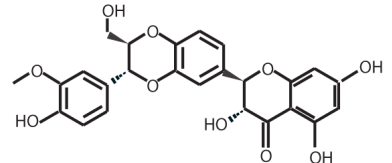

Silibinin

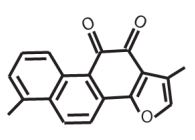

Tanshinone I<smiles>OCCC1CC2CC(C1)C2</smiles>

Tyrosol<smiles>O=C(O)[C@H](O)Cc1ccc(O)c(O)c1</smiles>

Salvianic acid A

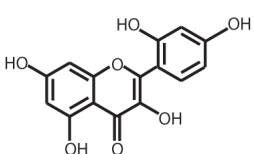

Morin

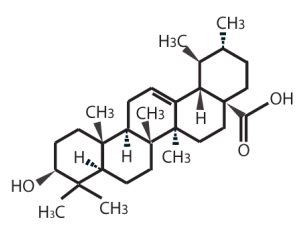

Ursolic acid 
Figure S2. Cytotoxicity assays demonstrated the toxic effects of human amylin against INS-1 pancreatic $\beta$-cells (panel A) and Neuro-2A neuronal cells (panel B), each at $5 \mu \mathrm{M}$ concentration. * Symbols indicate significantly reduced cell viability with amylin treatments in comparison with controls.

A

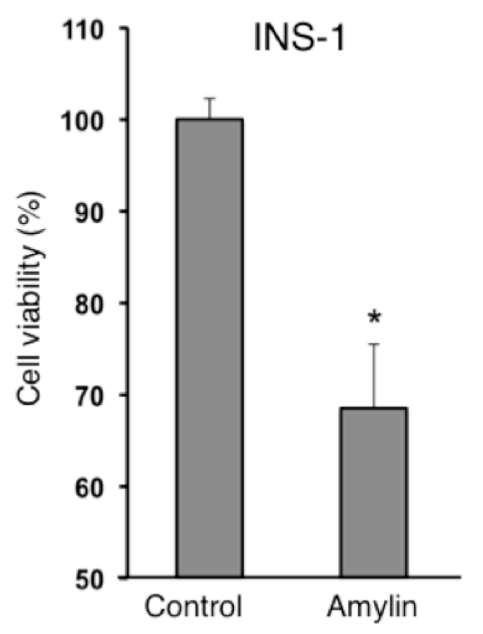

B

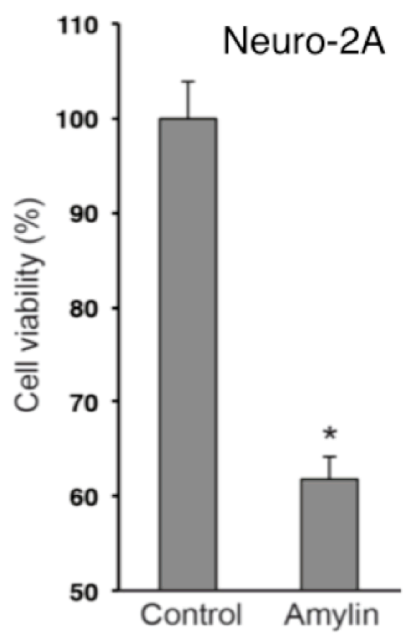


Figure S3. Cell viability assay demonstrates that baicalein itself has no significant effects to INS-1 cell viability at the concentrations from 1-75 $\mu \mathrm{M}$.

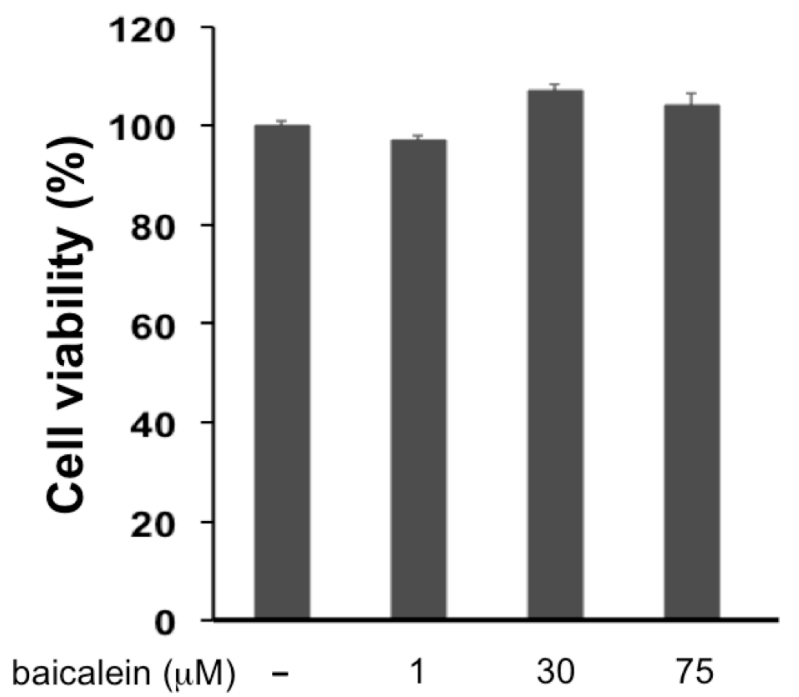


Figure S4. Mass information about the human amylin peptide and baicalein-amylin conjugated products. (A) Amino acid sequence of human amylin is shown. Theoretically calculated and observed monoisotopic masses are shown side by side in comparison. (B) Proposed mechanisms for the conjugation of baicalein to amylin (via oxidative Schiff based formation). Theoretically calculated and experimentally observed monoisotopic masses are shown side by side in comparison. The amylin peptides are schematically shown as filled black blocks.

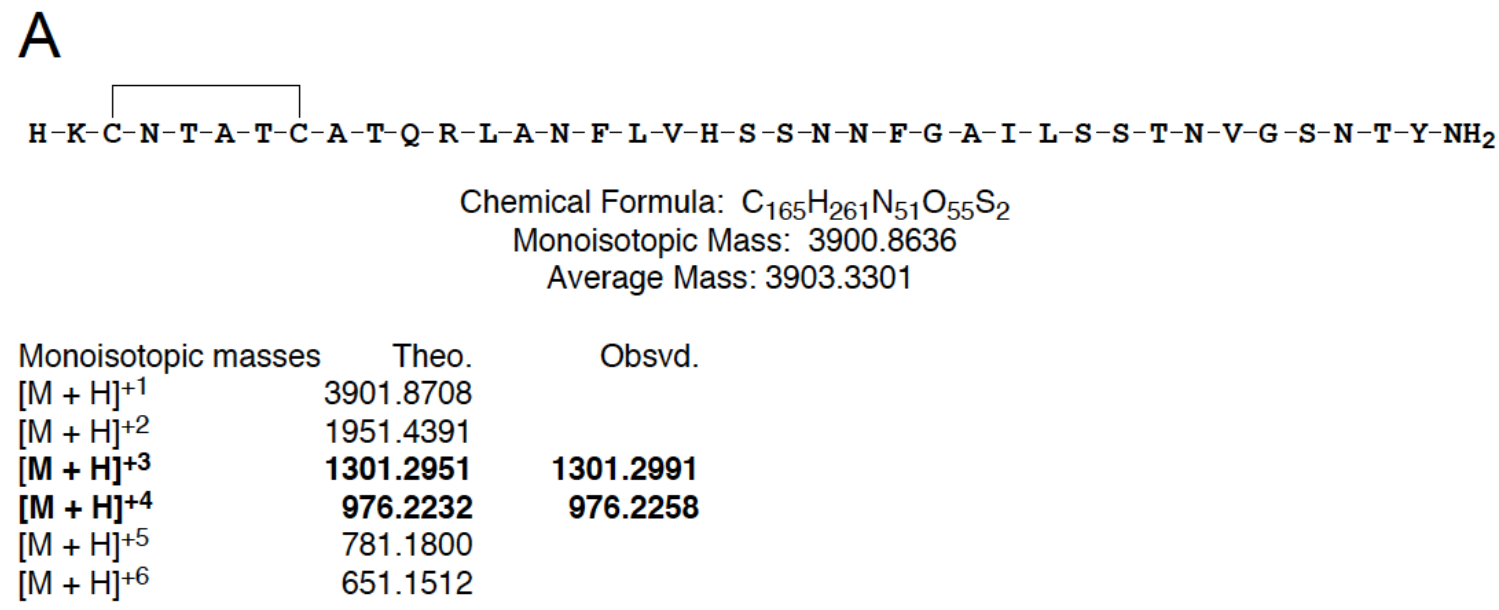

B<smiles>CC(C)CCN=C1C=c2oc(-c3ccccc3)cc(=O)c2=C(O)C1=O</smiles>

Chemical Formula: $\mathrm{C}_{15} \mathrm{H}_{10} \mathrm{O}_{5}$ Monoisotopic Mass: 270.0528 Average Mass: 270.2414
$\mathrm{C}_{180} \mathrm{H}_{267} \mathrm{~N}_{51} \mathrm{O}_{59} \mathrm{~S}_{2}$ Monoisotopic Mass: 4150.8902

Monoisotopic masses (Theo.)

$[\mathrm{M}+\mathrm{H}]^{+1} \quad 4151.8974$

$[\mathrm{M}+2 \mathrm{H}]^{+2} \quad 2076.4524$

$[\mathrm{M}+3 \mathrm{H}]^{+3} \quad 1384.6373$

$[\mathrm{M}+4 \mathrm{H}]^{+4} \quad 1038.7298$

$[\mathrm{M}+5 \mathrm{H}]^{+5} \quad 831.1853$

$[\mathrm{M}+6 \mathrm{H}]^{+6} \quad 692.8223$
$\mathrm{C}_{180} \mathrm{H}_{269} \mathrm{~N}_{51} \mathrm{O}_{59} \mathrm{~S}_{2}$ Monoisotopic Mass: 4152.9058

Monoisotopic masses (Theo.)

$[\mathrm{M}+\mathrm{H}]^{+1} \quad 4153.9131$

$[\mathrm{M}+2 \mathrm{H}]^{+2} \quad 2077.4602$

$[\mathrm{M}+3 \mathrm{H}]^{+3} \quad 1385.3092$

$[\mathrm{M}+4 \mathrm{H}]^{+4} \quad 1039.2337$

$[\mathrm{M}+5 \mathrm{H}]^{+5} \quad 831.5884$

$[\mathrm{M}+6 \mathrm{H}]^{+6} \quad 693.1582$

Monoisotopic masses (Obsvd.)

$[\mathrm{M}+3 \mathrm{H}]^{+3} \quad 1385.3097$

$[\mathrm{M}+4 \mathrm{H}]^{+4} \quad 1039.2354$ 